\title{
Ten minutes with Mrs Katya Tambe, Joint Head of Service, Ophthalmology Department, Nottingham University Hospitals NHS Trust, Nottingham, UK
}

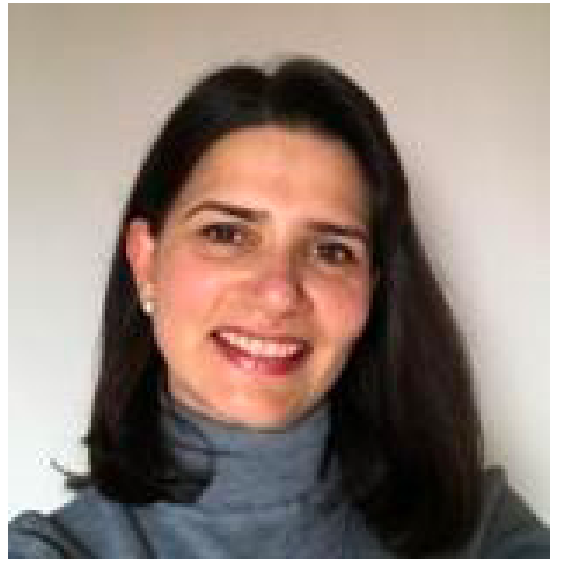

\section{WHAT ARE THE KEY LEADERSHIP MESSAGES YOU WANT TO} GET OUT TO THE BMJ LEADER READERSHIP?

From my personal experience through this COVID-19 crisis, my message is fourfold.

Communication is paramount. I know that effective communication is a cliché and everyone always talks about it, but at the start of the pandemic, we were in a state of flux with a flurry of new guidance and decisions emerging on a daily basis. We initially established a Monday morning management meeting to consolidate the emerging guidance and send out a clear, coherent message. This quickly evolved to become a daily meeting with social distancing measures, and we extended the invitation to the entire department via Microsoft Teams to maintain transparency, giving everyone the opportunity to contribute directly.

The second point, especially in a crisis, is to be supportive. It is natural for staff to be frightened, particularly in the early days when no one knew what the virus was about, but being there for each other and reassuring staff that we are all in this together brought people together.

Third, it is important to be fair and equitable. Initially, there was concern among our allied health professional (AHP) staff about being on the front line without adequate personal protective equipment (PPE). To address these concerns, my co-Head of Service (HoS) and I worked with the Nottingham University Hospitals NHS Trust (NUH) PPE steering group, which agreed that ophthalmologists and ophthalmic AHPs were at high risk of exposure due to their close proximity to patients. Together, we ensured that all our staff had access to appropriate PPE.

Finally, in a crisis situation, one can make hasty and rash decisions, but it is important to stop and think. One aspect I would have approached differently is the management of our cancelled clinics. As a high-volume outpatient department treating elderly patients with many comorbidities, it is a challenge to protect patients and staff while preventing vision loss from silent sight-threatening conditions, such as glaucoma and diabetic retinopathy. Perhaps, in place of cancelling all clinics at the outset, converting them into timetabled virtual clinics

\section{Biography}

Katya Tambe is the Joint Head of Service (HoS) for the ophthalmology department at Nottingham University Hospitals NHS Trust (NUH). She was appointed as a consultant ophthalmologist with a specialist interest in adult and paediatric oculoplastics in 2010.

Following her ophthalmic surgical training from the BJ Medical College in Pune, India and the West Midlands Deanery Birmingham, she went on to complete two prestigious oculoplastics fellowships at Leicester (2007-2008) and Moorfields Eye Hospital (2009-2010), in addition to a Paediatric Oculoplastics Fellowship at the Birmingham Children's Hospital in 2009.

She is the governance lead for paediatric ophthalmology at the Queen's Medical Centre and chairs the ophthalmic division of the League of Friends Charity at NUH. The COVID-19 pandemic has come as a challenge in her third year as the Joint HoS.

would have been an effective way for the administrative staff to keep track of patients and appointments.

\section{TELL US A LITTLE BIT ABOUT YOUR LEADERSHIP ROLE AND HOW IT IS CHANGING AS A RESULT OF THE PANDEMIC.}

I have coheaded the department since January 2018. We have 23 ophthalmology consultants, 12 trainees, along with staff grade, speciality and associate specialist (SAS) doctors, nurses and managers, altogether a total of 200 staff. We have around 160000 patient episodes every year, consulting and treating up to 500 patients a day, and we see more children than the hospital paediatric department.

Prior to COVID-19, the majority of my work was within the department, for example, working on patient safety improvement, streamlining theatre pathways and developing virtual clinics. This took up around $10 \%$ of my time with $90 \%$ being direct patient care. Since $23 \mathrm{March}$, I spend over 90\% of my time on management, working on new systems to drastically change the way we see patients. Spearheaded by one of our senior trainees, we are collaborating with clinical commissioning groups to rapidly develop integrated care systems which will help evolve our services from seeing patients faceto-face to virtual consultations.

I have had to adapt to things outside my sphere of work, such as junior doctor rotas, and decide who is fairly redeployed to help on the surgical wards. Our trainees who have been redeployed have been fantastic; they have done some excellent work on the wards and we are all very proud of them.

Having cancelled $90 \%$ of our elective work, it was important to effectively manage the remaining workforce to continue emergency eye care provision and triage the $7000+$ patients awaiting review prior to the COVID-19 crisis. As patient backlogs are increasing across the country in all ophthalmology departments, the pause in clinical activity had provided the 
perfect opportunity to risk stratify patients and allocate a review time frame as directed by NHS improvement (NHS-I).

\section{WHAT EVENTS IN YOUR PAST EXPERIENCE ARE MOST INFORMING YOUR LEADERSHIP IN THIS PANDEMIC?}

I was an intern in India during the plague of 1994, which affected mainly the Gujarat and Maharashtra regions. I remember the frenzy of staff and the public along with the stigmatisation of the plague and those affected. People had no idea where it had come from, not dissimilar to the initial misinformation around COVID-19 and rumours about how the virus spreads. From my memories of 25 years ago, I made it a point to be as well informed as possible about COVID-19 to help alleviate people's fears. It is important to be calm, fair and open so that people can trust you.

\section{WHAT ARE YOU FINDING THE BIGGEST CHALLENGES?}

First, the initial conflicting advice regarding PPE from Public Health England, the Royal College of Ophthalmologists and the nursing hierarchy. No one was singing from the same hymn sheet. NUH set up a steering group headed by a surgeon with a military background who appreciated that each specialty had different challenges and patient contacts. Once the PPE challenge was resolved, a big weight was lifted off me. Although we are not able to completely eliminate the risk of infection, protecting our patients and front-line staff from infection is of utmost importance, and the only way to do this is with adequate PPE.

As we ceased all elective activity from 16 March, the second challenge was to communicate to over 500 patients a day, advising them to not attend their appointments. This required a massive and speedy effort from our admin team; fortunately, this was aided by the government advice for those over 70 to stay at home.

The greatest challenge going forward for ophthalmology departments across the country is going to be the recovery phase. How do we deal with the pre-existing backlog of $7000+$ patients, along with the exponentially increasing numbers of patients we need to see? How do we ensure these patients are not slowly losing vision? When we restart our services, how do we ensure that our elderly patients with comorbidities can safely come into the department and not contract COVID-19? We are working with NHS-I and NHS England to explore different ways of collaborating with community optometrists and developing virtual clinics, which will help increase our capacity to see patients.

In addition, there are over a 1000 patients waiting to have surgery in ophthalmology alone. This is another colossal management exercise that we are working through.

\section{ANY PARTICULAR SURPRISES?}

Surprises have come, both positive and negative.

There was a big news announcement from the NHS stating that money was not an issue and anything related to COVID-19 would be sanctioned immediately. When it comes to ophthalmology, although we are not directly treating patients with COVID-19, we have a large group of patients who are at a high risk of sight loss if they are not managed on time. Virtual clinics are the ideal way to review high volumes of patients, ensuring only one patient is in the investigation suite for data collection at a given time, minimising the time patients spend in the department, thus reducing their risk of contracting COVID-19. While we had previously obtained approval for these clinics from the NUH board, in light of COVID-19-related funding changes, this process is now more drawn out. Each specialty unit has its own strategy for managing patients in the recovery phase and for Ophthalmology this is one of the most effective ways of seeing and treating high volumes of patients in the post-COVID-19 period. As we have already received funding from the League of Friends charity for the suite and the equipment, it is disappointing not to be allocated the funds to adequately staff this virtual clinic service.

On the other hand, the crisis has highlighted many positive events. A fantastic surprise came at the beginning when I reached out to the head of design and technology at my daughter's school, asking for their help in making slit lamp shields. Within a day, a team of year 12 students had manufactured 12 shields to use in our clinical areas to protect patients, nurses, optometrists and ophthalmologists. This just goes to show the sense of duty and love everyone has for the NHS. I was truly touched by their gesture.

While the junior doctors immediately rolled up their sleeves to help in eye casualty and other surgical wards, my consultant colleagues were instrumental in the departmental response to COVID-19. The medical retina team came together to swiftly draft a protocol for reviewing and treating patients with macular degeneration; the glaucoma team created guidelines for the risk stratification of glaucoma patients; the vitreoretinal consultants have been tirelessly operating on emergency cases, and the more tech-savvy consultants have spearheaded information technology solutions, including remote access from home. It has been wonderful to see everyone rally together and work towards mitigating the impact of the crisis.

\section{ARE YOU SEEING ANY BEHAVIOURS FROM COLLEAGUES THAT ENCOURAGE OR INSPIRE YOU?}

The first person that comes to mind is the Joint HoS working with me. To my surprise, on 16 March, having landed at Heathrow airport at 6:00, returning from lecturing in Brazil, he went home, showered and made it to the emergency meeting organised for 8:30. He worked that entire day and has been at work every single day since. His dedication is truly inspirational, especially as (I am sure he won't mind me saying this) he's not our youngest colleague, and in his words, 'the SARS2 virus doesn't know the difference between those who are 70 years or plus or minus a few'.

The Royal College of Ophthalmologists has been an excellent resource. I am inspired by colleagues who have openly shared their plans and ideas on the clinical leads forum. The risk stratification that came out from the Moorfields team was revised from the forum feedback and is now being used across the country.

The younger consultants in our department immediately offered to go and help on the COVID-19 wards, their drive to help was contagious.

\section{HOW ARE YOU MAINTAINING KINDNESS AND COMPASSION?}

In the initial stages, there was a feeling among AHPs that they were a forgotten group. This disheartened me and ever since I have tried to keep in touch with everyone, from colleagues who are self-isolating to registrars who have been redeployed. The other thing I do, perhaps once a week, is to make an active effort to walk around the entire department and check in with everyone; this has been widely appreciated. 


\section{ARE THERE ANY IDEAS OR READINGS THAT YOU FIND HELPFUL FOR INSPIRATION AND SUPPORT, WHICH YOU WOULD RECOMMEND TO OTHERS?}

I have been reading The Falcon of Sparta by Conn Iggulden, who writes historical fiction. The setting is a Persian war in 400 BC between the Greek Spartans and Persians. As all the generals in the Greek army are killed by the Persians, it falls to a young 30-year-old philosopher, Xenophon, to rise to the challenge and lead 10000 troops against the legendary Persian warriors.

One has to rise to the mark when there is a problem and go above and beyond what ones' capabilities are, which I hope I have managed to do. His aim was to take his troops safely back to Greece, and my aim was to lead my patients and staff safely through COVID-19.

\section{WHAT ARE YOU LOOKING FOR FROM YOUR LEADERS?}

At the beginning of March, our medical director spoke to all the HoSs, and what he said was very striking. He said, 'I look to you for advice as to how we're going to overcome this crisis, because each one of you know what is needed in your particular area', and I think he got it right. 'Let us tell you what we need in our individual areas, then you can make an informed decision at the wider Trust level'.

For our junior doctors, I would say continue to lead in your own spheres and continue the great work that you are doing.

\section{Katya Tambe, Bansri Lakhani}

Ophthalmology, Nottingham University Hospitals NHS Trust, Nottingham, UK

\section{Correspondence to}

Miss Bansri Lakhani, Ophthalmology Department, Nottingham University Hospitals NHS Trust, Nottingham NG7 2UH, UK; bansrilakhani11@gmail.com
Contributors KT was interviewed by $B L ; B L$ documented and formatted the article for submission. KT and BL checked and revised the manuscript prior to submission.

Funding The authors have not declared a specific grant for this research from any funding agency in the public, commercial or not-for-profit sectors.

Competing interests None declared.

Patient consent for publication Not required.

Provenance and peer review Not commissioned; internally peer reviewed.

Data availability statement Data sharing not applicable as no datasets generated and/or analysed for this study.

\section{(2) \\ OPEN ACCESS}

Open access This is an open access article distributed in accordance with the Creative Commons Attribution Non Commercial (CC BY-NC 4.0) license, which permits others to distribute, remix, adapt, build upon this work non-commercially, and license their derivative works on different terms, provided the original work is properly cited, appropriate credit is given, any changes made indicated, and the use is non-commercial. See: http://creativecommons.org/licenses/by-nc/4.0/.

(c) Author(s) (or their employer(s)) 2020. Re-use permitted under CC BY-NC. No commercial re-use. See rights and permissions. Published by BMJ.

\section{Check for updates}

To cite: Tambe K, Lakhani B. BMJ Leader 2020;4:248-250.

Received 7 May 2020

Revised 17 May 2020

Accepted 20 May 2020

Published Online First 2 June 2020

BMJ Leader 2020;4:248-250.

doi:10.1136/leader-2020-000285

ORCID iD

Bansri Lakhani http://orcid.org/0000-0003-3838-0865 